Profit: Jurnal Kajian Ekonomi dan Perbankan 3 (2) 2019. P: 50-66

PROFIT : JURNAL KAJIAN EKONOMI DAN PERBANKAN https://ejournal.unuja.ac.id/index.php/profit

P-ISSN : 2685-4309 E-ISSN : 2597-9434

\title{
MOTIVASI KERJA DALAM PENGEMBANGAN USAHA PERSPEKTIF EKONOMI ISLAM (Studi Pada Waralaba Kebab Turki Baba Rafi di Surabaya)
}

\author{
Saifuddin, M.E * \\ sailmuda91@unuja.ac,id \\ Program Studi Ekonomi Syariah, Fakultas Agama Islam Universitas Nurul Jadid Paiton
}

\begin{abstract}
Abstrac
Kebab Turki Baba Rafi franchise is one of the pioneers of kebab food in Indonesia, one of the worldwide local franchisees, and a work motivation that aspires to be the largest franchise in the world. Kebab Turki Baba Rafi has made a major contribution to the economy in Indonesia, by implementing a precise development strategy. Work motivation plays an important role in developing business in Kebab Turki Baba Rafi. This motivation is what makes the success of Kebab Turki Baba Rafi to successfully penetrate the international market. This study aims to reveal and analyze: (1) what work motivation is applied in Kebab Turki Baba Rafi (2) contributions made, and (3) its development strategy, the approach used in this research is descriptive qualitative research with survey research methods. Data collection is done by interview, observation and documentation. Data analysis techniques using the theory of Miles and Huberman which is done in three steps, namely: data reduction, data presentation, and conclusions. The checking of the validity of the data is done by: (1) checking the methodology used, (2) correcting the results of the research report, (3) triangulating sources and methods. The results of the study found several factors of work motivation that were applied including: (1) achievement, namely giving a bonus if it exceeded the sales target, (2) responsibility, namely decisive in enforcing regulations and punishing those who made mistakes, (3) development, namely providing guidance in every religion once a month. (4) administrative policy, namely providing direction using good and polite speech, (5) interpersonal relationships that are mutually supportive, (6) working conditions namely providing comfort and complete work facilities. His contribution provides extensive employment, creating professional expertise. Whereas in its development strategy applying the Prophet's business style which includes Shiddiq, Amanah, Tabligh, and Fatanah
\end{abstract}




\section{Pendahuluan}

Catatan yang disampaikan Yayasan Indonesia Forum, untuk mencapai Visi Indonesia 2030 ada beberapa persyaratan yang harus dipenuhi, yaitu: reformasi perpajakan, reformasi birokrasi, reformasi system hukum, good governance yang ditunjang semua komponen bangsa, serta adanya pemimpin yang memiliki a vision and strong leadership. ${ }^{1}$

Amanat Ketetapan Majelis Permusyawaratan Rakyat Republik Indonesia Nomor XVI/MPRRI/1998 tentang Politik Ekonomi dalam rangka Demokrasi Ekonomi, Usaha Mikro Kecil dan Menengah perlu diberdayakan sebagai bagian integral ekonomi rakyat yang mempunyai kedudukan, peran, dan potensi strategis untuk mewujudkan struktur perekonomian nasional yang makin seimbang, berkembang, dan berkeadilan. ${ }^{2}$

Hasil paparan data BPS menjelaskan perkembagan UKM dari tahun 1997-2012 mengalami pertumbuhan $2,41 \%{ }^{3}$ Penduduk Indonesia $70 \%$ berada pada usia produktif, dan jumlah angka kerja pada tahun 2014 ialah 121.870 .000 dan 55 juta adalah pekerja terampil. ${ }^{4}$ Pengembangan dan pemberdayaan Usaha Kecil dan Menengah (UKM) merupakan isu sentral yang sangat strategis, karena UKM terbukti memiliki kontribusi yang besar dalam perkembangan perekonomian nasional diantaranya memberikan kontribusi sekitar 57,9\% terhadap Pendapatan Domestik Bruto (PDB) dan memiliki kemampuan dari segi penyerapan tenaga kerja yang sangat tinggi sekitar 97,3\%, serta lebih tahan terhadap krisis ekonomi.

Di negara berkembang seperti Indonesia, pemerintah tidak sepenuhnya sanggup menyediakan lapangan pekerjaan, maka UKM memiliki keunggulan tertentu sebagai kontributor dalam pertumbuhan ekonomi melalui : Pertama, UKM umumnya tidak menerapkan teknologi canggih sehingga mampu menyerap tenaga kerja yang memiliki tingkat pendidikan rendah. Kedua, melalui kemampuan kewirausahaan dan kemampuan kompetisi UKM dapat menjadi sumber pertumbuhan ekonomi dan inovasi. Ketiga, dengan semakin berkembangnya perusahaan UKM persaingan semakin meningkat dan diharapkan mampu memacu pertumbuhan ekonomi suatu daerah. Keempat, UKM memberi kontribusi pada pemerataan pendapatan karena tidak terkonsentrasi di suatu daerah. ${ }^{5}$

Untuk menjalankan UKM tidak perlu bermodal besar dan tenaga kerja yang dipekerjakan tidak perlu memiliki standar pendidikan tertentu sebagaimana dipersyaratkan pada perusahaan besar. Selain itu pengurusan izinnya pun dipermudah oleh Pemerintah. Dengan kondisi tersebut memungkinkan pelaku usaha UKM membuka usaha baik di rumah, menyewa kios, kontrak ruko, berjualan di pasar atau dengan menggunakan gerobak dorong.

Sebagai negara berkembang, Indonesia sangat penting untuk memperhatikan UKM. Alasannya UKM mempunyai kinerja lebih baik dalam menyediakan tenaga kerja yang produktif dan mampu hidup di sela-sela usaha besar. UKM mampu menopang usaha besar seperti menyediakan bahan mentah, suku cadang dan bahan pendukung lainnya. UKM juga mampu menjadi ujung tombak bagi usaha besar dalam menyalurkan dan menjual produk dari usaha besar ke konsumen. ${ }^{6}$

${ }^{1}$ Adi Sulistyono, Hukum Ekonomi Sebagai Panglima, Cetakan pertama, (Sidoarjo, Masmedia Buana Pustaka, 2009), hal 3

${ }_{2}^{2}$ Klausul menimbang huruf a, Undang-Undang No 20 Tahun 2008 Tentang Usaha Mikro, Kecil dan Menengah

${ }^{3}$ www.bps.go.id

${ }^{4}$ World Bank, statistic Indonesia, McKinsey, 2014

${ }^{5}$ Bambang N Rachmadi, Franchising The most Practical and Excellent Way of Succeeding, Cetakan kedua, (Jakarta, Gramedia Pustaka Utama, 2007), hal 12

${ }^{6}$ Gatut Susanto dan M.Azrin Syamsuddin, Cara Mudah Mendirikan dan Mengelola UMKM, Cetakan pertama, (Depok, Raih Asa Sukses, 2009), hal 6 
Bisnis waralaba di Indonesia saat ini telah merebak dan mulai dikuasai pebisnis lokal. Masyarakat kita mulai sadar bahwa waralaba adalah alternatif penting dalam rangka menggairahkan perekonomian nasional setelah metode distributorship dan keagenan telah meredup sehingga mulai ditinggalkan. Perbedaan antara distributor dan agen terletak dalam hal tanggung jawab terhadap pihak ketiga. Distributor bertindak untuk dan atas nama sendiri dan bertanggung jawab sepenuhnya atas tindakannya, sedangkan agen bertindak untuk dan atas nama prinsipal sehingga segala perbuatan agen menjadi tanggung jawab prinsipal.

Kita harus mengakui bahwa peran usaha kecil dan menengah (UKM) yang jumlahnya sangat dominan dalam struktur perekonomian Indonesia sangat strategis dan seharusnya dijadikan landasan pembangunan ekonomi nasional. Namun fakta menunjukkan perekonomian nasional lebih dikuasai segelintir penguasa besar yang ternyata sangat labil terhadap goncangan ekonomi global. Masalahnya adalah, bagaimana memperluas dan memberdayakan UKM yang cenderung masih menerapkan menejemen tradisional, lemah terhadap akses permodalan, teknologi cenderung yang konvensional, miskin inovasi dan jaringan, sehingga mampu bersama-sama tumbuh dengan perusahaan besar terutama yang berkelas dunia.

Waralaba menjadi alternatif pilihan, karena melalui bisnis waralaba, UKM penerima waralaba akan mendapatkan, 1) transfer manajemen, 2) kepastian pasar, 3) promosi, 4) pasokan bahan baku, 5) pengawasan mutu, 6) pengenalan dan pengetahuan tentang lokasi bisnis, 7) pengembagan kemampuan sumber daya manusia, dan yang paling penting adalah resiko dalam bisnis waralaba yang sangat kecil. ${ }^{7}$ Bisnis waralaba itu berbeda dibandingkan dengan bisnis lainnya. Bisnis waralaba tidak hanya sekedar menjual produk, tetapi juga menjual HKI (Hak atas Kekayaan Intelektual). Inilah salah satu keunggulan bisnis waralaba, sehingga tidak mudah ditiru oleh pelaku bisnis lain. HKI berperan penting dalam melindungi pemilik produk atau bisnis aslinya supaya tetap dapat berproduksi atau melakukan bisnisnya secara eksklusif. ${ }^{8}$

Salah satu waralaba produk lokal yang merajai pangsa pasar yaitu Kebab Turki Baba Rafi milik Hendy Setiono yang telah memiliki lebih dari 1000 outlet yang ada di indonesia, bahkan sudah sampai melebarkan sayap sampai ke luar negeri. ${ }^{9}$ Kebab Turki Baba Rafi merupakan pioner waralaba Kebab Lokal di Indonesia, dan telah meraih beberapa penghargaan diantaranya ISMBEA (Indonesian Small Medium Business Entrepreneur Award) 2006 yang diberikan menteri koperasi dan UKM, FRANCHISE TERBAIK 2007 bidang Makanan dan Minuman versi Majalah Pengusaha dan tahun 2008 mendapat penghargaan Indonesia Franchise Award 2008 sebagai kategori - Top 10 Indonesia Franchisor.

Segala sesuatu yang ingin dicapai pasti memerlukan yang namanya sebuah motivasi. Motivasi dalam segala hal sangat penting, dan ini yang mendorong tercapainya tujuan yang diinginkan, begitu juga dengan motivasi kerja, hal ini memberikan kontribusi yang sangat besar bagi suatu pelaku usaha, khususnya di bidang waralaba, berkembang tidaknya usaha tergantung dari tingkat motivasi kerja itu sendiri. Langkah sukses Kebab Turki Baba Rafi ini tidak terlepas dari motivasi kerja yang sudah diterapkan, seperti dalam pengembangan usahanya.

\section{Pengertian Motivasi Kerja}

Dalam pengertian umum, motivasi dikatakan sebagai kebutuhan yang mendorong perbuatan ke arah suatu tujuan tertentu. Batasan mengenai motivasi sebagai "The process by which behavior is

\footnotetext{
7 Tunggal, Freaquently Ask, hal iv-v

${ }^{8}$ Suryono Ekotama, Cara Gampang Bikin Bisnis Franchise, (Yogyakarta: Media Pressindo, 2008), hal 57

9 http://sp.beritasatu.com/ekonomidanbisnis/kebab-baba-rafi-rambah-malaysia-dan-filipina/17072 diakses
} $\operatorname{tgl} 26-08-2016$ jam 21:54 
energized and directed" (suatu proses, dimana tingkah laku tersebut dipupuk dan diarahkan) para ahli psikologi memberikan kesamaan antara motif dengan needs (dorongan, kebutuhan). Dari batasan di atas, dapat disimpulkan bahwa motif adalah yang melatar belakangi individu untuk berbuat mencapai tujuan tertentu. ${ }^{10}$

Sedangkan pengertian mengenai motivasi adalah pemberian atau penimbulan motif, dapat pula diartikan hal atau keadaan menjadi motif. Jadi motivasi kerja adalah sesuatu yang menimbulkan semangat atau dorongan kerja. Kuat atau lemahnya motivasi kerja seorang tenaga kerja ikut menentukan besar kecilnya prestasi.

Menurut Stephen P. Robbins dan Timothy A. Judge mendefinisikan motivasi (motivation) sebagai proses yang menjelaskan 9 intensitas, arah dan ketekunan seseorang individu untuk mencapai tujuannya. $^{11}$

Menurut Melayu, motivasi adalah pemberian daya penggerak yang menciptakan kegairahan kerja seseorang, agar mereka mau bekerja sama, bekerja efektif, dan terintegrasi dengan segala daya upayanya untuk mencapai kepuasan. Menurut Herold Koontz, motivasi mengacu pada dorongan dan usaha untuk memuaskan kebutuhan atau suatu tujuan. Sedangkan menurut Wayne F. Cassio, motivasi adalah sesuatu kekuatan yang dihasilkan dari keinginan seseorang untuk memuaskan kebutuhannya (misalnya : rasa lapar, haus dan bermasyarakat). ${ }^{12}$

Filmore H. Stanford, mengatakan motivasi sebagai suatu kondisi yang menggerakkan manusia ke arah suatu tujuan tertentu. Menurut Robert A. Baron, motivasi dapat pula dikatakan sebagai energi untuk membangkitkan dorongan dalam diri (drive aurosal). Bila suatu kebutuhan tidak terpuaskan, timbul drive dan aktivitas individu untuk merespon perangsang (incentive) dalam tujuan yang diinginkan. Pencapaian tujuan akan menjadikan individu merasa puas. ${ }^{13}$

Dalam hubungannya dengan lingkungan kerja Ernest J. McCormick mengemukakan bahwa motivasi kerja adalah suatu kondisi yang mempengaruhi, membangkitkan, mengarahkan dan memelihara perilaku yang berhubungan dengan lingkungan kerja. ${ }^{14}$ Dalam memotifasi karyawan, pimpinan disamping harus memperhatikan dan mempertimbangkan secara kualitatif kemampuan dan potensi psikis mereka agar dapat disumbangkan semaksimal mungkin untuk keberhasilan organisasi. Selain itu juga perlu memperhatikan dan mempertimbangkan apa yang menjadi kebutuhan-kebutuhan para karyawan.

Dari pengertian para tokoh di atas maka, dapat disimpulan bahwa motivasi kerja adalah dorongan yang menggerakkan seseorang dalam bekerja untuk melakukan pekerjaan dengan segala upaya dan bekerja secara efektif untuk mencapai tujuan yang ingin dicapai. Juga dapat dikatakan motivasi kerja adalah dorongan, upaya dan keinginan yang ada dalam diri manusia yang mengaktifkan, memberi daya serta mengarahkan perilaku dalam pelaksanaan tugas di lingkungan pekerjaannya. Hakikat dari motivasi kerja adalah dorongan untuk melakukan segala sesuatu yang lebih baik dari yang lainnya dalam melakukan kegiatan untuk mencapai tujuan. ${ }^{15}$

${ }^{10}$ Pandji Anoraga, Psikologi Kerja.(Jakarta : PT Rineka Cipta,1992), hal 34

11 Stephen P. Robbins, Timothy A. Judge. Perilaku Organisasi, edisi ke 12 buku 1.(Jakarta: Salemba empat,2008), hlm. 222

${ }^{12}$ Hasibuan, Melayu. Managemen dasar, pengertian dan masalah. Refisi F. d. (Jakarta : Rajawali, 2001), hal 219

\footnotetext{
13 Anwar ,Prabu Mangkunegara. Psikologi Perusahaan. (Bandung: Trigenda karya, 1993), Hal 46

${ }^{14}$ Anwar, Psikologi Perusahaan, hal 47

${ }^{15}$ Husein Umar, 2002. Metode Riset Bisnis, (Jakarta, PT. Gramedia Pustaka Utama), hal 274
} 


\section{Teori-Teori Motivasi Kerja}

Teori-teori motivasi dapat digolongkan menjadi tiga klasifikasi teori. Teori-teori tersebut antara lain.
a. Teori Isi (Content Theory)
b. Teori Proses (Process Theory)
c. Teori Penguatan (Reinforcement Theory)

1. Teori Isi (Content Theory)

Teori-teori pada bagian ini mendasarkan pemikirannya pada pendekatan kebutuhan dan kepuasan individu. Kebutuhan dan kepuasan individu adalah hal penggerak mengapa individu itu bertindak dan berperilaku dengan cara tertentu. Teori ini mencoba menjawab pertanyaan kebutuhan apa yang memuaskan dan mendorong semangat kerja seseorang. Apabila kebutuhan dan kepuasannya terpenuhi maka seseorang akan semakin giat bekerja. Semakin tinggi standar kebutuhan dan kepuasan yang diinginkan maka semakin semangat bekerja seseorang.

2. Teori Proses (Process Theory)

Teori-teori proses berusaha agar setiap pekerja mau bekerja giat sesuai dengan harapan. Daya penggerak yang memotivasi semangat kerja terkandung dari harapan yang akan diperolehnya. Apabila harapan menjadi kenyataan maka pekerja cenderung akan meningkatkan kualitas kerjanya, begitu pula sebaliknya. Teori proses berasumsi bahwa motivasi timbul karena adanya kebutuhan (needs), kemudian ada harapan (expectancy) terhadapa kemungkinan balasan (reward) yang dapat digunakan dalam pemenuhan kebutuhan tersebut. Valence atau kekuatan keinginan seseorang terhadap balasan (reward) juga akan menentukan seberapa besar motivasi seseorang. Faktor tambahan dalam motivasi adalah valensi atau kekuatan dan preferensi seorang individu terhadap hasil yang diharapkan. ${ }^{16}$

3. Teori Penguatan (Reinforcement Theory)

Menurut pandangan ini orang akan bertindak menurut cara-cara tertentu. Hal tersebut dikarenakan dimasa lalu, mereka belajar bahwa perilaku-perilaku tertentu dihubungkan dengan hasil-hasil yang menyenangkan dan perilaku-perilaku tertentu lainnya, dihubungkan dengan hasil-hasil yang kurang menyenangkan. Jika teori isi mencoba menjelaskan motivasi "apa" dan teori proses menjelaskan "bagaimana", teori penguatan mencoba menjelaskan peranan balasan (reward) dalam membentuk perilaku tertentu. Teori ini berasumsi apabila suatu perilaku diberikan balasan menyenangkan (rewarding) maka perilaku itu akan diulangi. Namun apabila diberikan balasan hukuman (punishment) makan perilaku itu tidak akan diulang lagi di masa datang. Proses penguatan (reinforcement) meliputi tahapan stimulus, respon, konsekuensi dan respon masa mendatang. ${ }^{17}$

\section{Faktor-Faktor yang Mempengaruhi Motivasi}

Faktor-faktor yang memotivasi karyawan sebagaimana yang dipaparkan menurut teori Herzberg adalah sebagai berikut:

16 Veithzal, Rivai, Managemen Sumber Daya Manusia Untuk Perusahaan, Dari Teori Ke Preaktek, (Jakarta, PT. Raja Grafindo Persada, 2004), hal 171

${ }_{17}$ Azwar Sanusi, Tesis Ilmu Komunikasi: Pengaruh Motivasi Kerja dan Iklim Komunikasi Organisasi terhadap Komitmen Keorganisasian Pegawai Arsip Nasional Republik Indonesia, (Universitas Indonesia, 2012), hal 42 


\section{Motivation factor (Faktor Intrinsik)}

Faktor-faktor yang berperan sebagai motivator terhadap karyawan, yakni mampu memuaskan dan mendorong orang untuk bekerja lebih baik. Faktor motivator ini terdiri dari:

a. Prestasi (achievement)

Agar seseorang karyawan dapat berhasil dalam pelaksanaan pekerjaannya, maka pemimpin harus mempelajari bawahannya dan pekerjaannya dengan memberikan kesempatan kepadanya agar bawahan dapat berusaha mencapai hasil. Kesempatan itu harus sedemikian rupa sehingga orang-orang berkembang sendiri.

Selanjutnya agar pemimpin memberi semangat pada para bawahannya sehingga bawahan mau berusaha mengerjakan sesuatu yang dirasakan bawahan tidak dapat dikuasainya. Bila bawahan telah berhasil mengerjakan pekerjaannya, pemimpin harus menyatakan keberhasilan itu.

b. Pengakuan (Recognition)

Sebagai lanjutan dari keberhasilan pelaksanaan, pimpinan harus memberi pernyataan pengakuan akan keberhasilan tersebut. Pengakuan terhadap keberhasilan bawahan dapat dilakukan dengan berbagai cara yaitu :

1) Langsung menyatakan keberhasilan di tempat kerjanya, lebih baik dilakukan sewaktu ada orang lain.

2) Surat penghargaan.

3) Memberi hadiah berupa uang tunai.

4) Memberikan medali, surat penghargaan dan hadiah uang tunai.

5) Memberikan kenaikan gaji dan promosi.

6) Pekerjaan itu sendiri (the work it self).

Pimpinan membuat usaha-usaha riil dan meyakinkan, sehingga bawahan mengerti akan pentingnya pekerjaan yang dilakukannya. Pimpinan juga akan berusaha menghindarkan bawahannya dari kebosanan dalam pekerjaan, serta mengusahakan agar setiap bawahan sudah tepat dalam pekerjaanya.

c. Tanggung Jawab (Responsibility)

Agar Responsibility benar-benar menjadi factor motivator bagi bawahan, pemimpin harus menghindari supervise yang ketat, dengan membiarkan bawahan bekerja sendiri sepanjang pekerjaan itu memungkinkan dan menerapkan prinsip partisipasi. Diterapkannya prinsip partisipasi membuat bawahan sepenuhnya merencanakan dan melaksanakan pekerjaanya.

d. Pengembangan (advancement)

Advancement merupakan salah satu faktor motivator bagi bawahan. Faktor Advancement ini benar-benar berfungsi sebagai motivator, maka pemimpin dapat memulainya dengan melatih bawahannya untuk pekerjaan yang lebih bertanggung jawab. Bila ini sudah dilakukan selanjutnya pemimpin memberi rekomendasi tentang bawahan yang siap untuk pengembangan, untuk menaikkan pangkatnya, dikirim mengikuti pendidikan atau pelatihan selanjutnya.

2. Maintenance Factor (Faktor Ekstrinsik)

Orang belum dapat mencapai faktor kepuasan, sebelum kekecewaan didalam pekerjaan dapat dihilangkan lebih dahulu. Agar kekecewaan dapat dihilangkan dari pekerjaan, maka pimpinan harus melakukan tindakan sebagai berikut.

a. Kebijakan dan Administrasi dari perusahaan, yang menjadi sorotan disini adalah kebijaksanaan personalia. Policy personalia umumnya dibuat dalam bentuk tertulis. Biasanya yang dibuat dalam bentuk tertulis itu baik, dan yang utama adalah bagaimana pelaksanaan dan praktiknya. Pelaksanaan kebijaksanaan dilakukan masing-masing manajer agar apa 
yang ditulis benar-benar direalisasikan dalam praktik oleh masing-masing manajer yang bersangkutan. Dalam hal ini supaya mereka berbuat seadil-adilnya.

b. Supervisi (quality supervisor), dengan Technical Supervisior yang menimbulkan kekecewaan dimaksud adanya kekurang mampuan di pihak atasan. Diantarnya bagaimana caranya mensupervisi dari segi teknis pekerjaan yang merupakan tanggung jawabnya atau atasan mempunyai kecakapan teknis yang lebih rendah dari yang diperlukan dari kedudukannya. Untuk mengatasi hal ini para manajer harus berusaha memperbaiki dirinya dengan jalan mengikuti pelatihan dan pendidikan.

c. Hubungan antar pribadi (interpersonal relation), ini menunjukkan hubungan perseorangan antara bawahan dengan atasannya. Dimana kemungkinan bawahan merasa tidak dapat bergaul dengan atasannya. Agar tidak menimbulkan kekecewaan karyawan, maka minimal tiga kecakapan harus dimiliki setiap manajer yakni.

1) Technical skill (kecakapan teknis), kecakapan ini sangat penting bagi pimpinan tingkat terbawah dan tingkat menengah. Hal ini meliputi kecakapan menggunakan metode dan proses, yang pada umumnya berhubungan dengan kemampuan menggunakan alat.

2) Human skill (kecakapan kemanusiaan), kecakapan kemanusiaan adalah kemampuan untuk bekerja didalam atau dengan kelompok, sehingga dapat membangun kerja sama dan mengkoordinasikan berbagai kegiatan.

3) Conceptual skill (kecakapan konseptual), kecakapan konseptual adalah kemampuan memahami kerumitan organisasi sehingga dalam berbagai tindakan yang diambil tekanan selalu dalam usaha merealisasikan tujuan organissasi sebagai keseluruhan.

d. Kondisi kerja (working condition), masing-masing manejer dapat berperan dalam berbagai hal agar keadaan masing-masing bawahan menjadi lebih sesuai. Misalnya ruangan khusus bagi unitnya, penerangan, perabotan, suhu udara, dan kondisi fisik lainnya. Menurut Hezberg seandainya kondisi lingkungan yang baik dapat tercipta, maka prestasi tinggi dapat tercipta. Prestasi tinggi dapat dihasilkan melalui konsentrasi pada kebutuhankebutuhan ego dan perwujudan diri yang lebih tinggi.

e. Gaji (wages), pada umumnya masing-masing manajer tidak dapat menentukan sendiri skala yang berlaku dalam unitnya. Namun demikian masing-masing manejer mempunyai kewajiban menilai apakah jabatan-jabatan di bawah pengawasannya mendapat kompensasi sesuai pekerjaan yang mereka lakukan. Para manajer juga harus berusaha untuk mengetahui bagaimana jabatan di dalam perusahaannya diklasifikasikan dan elemen-elemen apa saja yang menentukan pengklasifikasian itu. ${ }^{18}$

Dari semua faktor yang telah disebutkan dapat disimpulkan bahwa terdapat banyak faktor yang memotivasi karyawan, diantaranya faktor intrinsik dan ekstrinsik. Keduanya memiliki dasar yang berbeda, faktor intrinsik lebih dipengaruhi oleh motivasi dalam diri yaitu keinginan dari seorang individu akan sebuah penghargaan, pengakuan, kepercayaan, tanggung jawab, dan kesempatan pengembangan diri. Sedangkan motivasi ekstrinsik lebih dipengaruhi oleh faktor dari luar seperti faktor gaji, lingkungan kerja, hubungan antar manusia dan kebijakan-kebijakan dalam perusahaan.

\section{METODE PENELITIAN}

Penelitian ini adalah penelitian kualitaif, dimana peneliti akan meneliti objek yang dituju sebagai acuan arti penelitian ini. Dalam literatur metodologi penelitian, Istilah kualitatif tidak hanya lazim

${ }^{18}$ Buchari, Zainun, Manajemen dan Motivasi, (Jakarta, Balai Aksara, 1989), hal 93 
dimaknai sebagai jenis data, tetapi juga berhubungan dengan analisis data dan interpretasi atas objek kajian. Secara historis, implementasi penelitian kualitatif bermula dari pengamatan. ${ }^{19}$

Adapun jenis penelitian ini adalah penelitian lapangan atau studi lapangan. Penelitian kualitatif jenis penelitian deskriptif dengan metode penelitian survei adalah penyelidikan yang diadakan untuk memperoleh fakta-fakta dari gejala-gejala yang ada, dan mencari keterangan-keterangan secara faktual, baik tentang institusi sosial, ekonomi, atau politik dari suatu kelompok ataupun suatu daerah..$^{20}$ Penelitian Lapangan (Field Research) dapat juga dianggap sebagai pendekatan luas dalam penelitian kualitatif atau sebagai metode mengumpulkan data kualitatif. Ide pentingnya adalah bahwa peneliti berangkat ke "lapangan" untuk mengadakan pengamatan tentang sesuatu fenomena dalam suatu keadaan alamiah. Peneliti lapangan biasanya membuat catatan lapangan secara ekstensif yang kemudian dibuatkan kodenya dan dianalisis. ${ }^{21}$

Penelitian memiliki tiga tahapan penting Tahapan-tahapan tersebut meliputi tahap persiapan, tugas lapangan, dan tahap analisis. Tahap persiapan dalam hal ini meliputi pemilihan judul, studi pustaka, perumusan masalah, perumusan tujuan, penentuan metode penelitian, dan penetapan waktu penelitian. Pemilihan judul dilakukan dengan terlebih dahulu melihat fenomena yang terjadi ditengah masyarakat. Setelah memahami isi dari fenomena, lalu peneliti mencari inti permasalahan yang menjadi solusi terkait motivasi kerja dalam pengembangan usaha. Tentu saja fenomena yang berusaha dicari di sini adalah fenomena yang belum pernah dibicarakan dalam penelitian sejenis sebelumnya.

\section{Hasil Penelitian}

Hasil dari penelitian ini akan peneliti olah berdasarkan hasil observasi, wawancara dan dokumentasi yang sudah dijabarkan sebelumnya, yaitu sebagai berikut:

\section{Motivasi Kerja Kebab Turki Baba Rafi}

Perusahaan sangat menghargai para karyawan yang berprestasi Hal ini dibuktikan dengan memberikan kenaikan pangkat, bahkan sampai dibiayai S2 full sampai lulus. Disamping itu penghargaan yang diterima oleh perusahaan akan memberikan nilai lebih dalam memotivasi agar menjadi perusahaan yang lebih baik lagi kedepannya. Selain itu, pentingnya nilai keikhlasan dapat dilihat dari loyalitas antar karyawannya, seperti ikhlas saling tolong menolong. Pendiri waralaba KTBR menjelaskan awal mula menjalankan bisnis untuk memenuhi kebutuhan hidup keluarga, yang pada saat itu mempunyai tanggung jawab sebagai kepala keluarga bagi istri dan ketiga anaknya. Perusahaan KTBR menyadari pentingnya menciptakan SDM yang berkompeten dunia akhirat. Dibuktikan dengan melaksanakan breafing rutin setiap hari Selasa dan Kamis yang meliputi pembelajaran keagamaan. Disamping itu juga pengalaman dari pendiri yang jatuh bangun membangun usaha, bisa menjadikan pembelajaran bagi generasi muda kedepannya. Hal itu dilakukan dengan cara mengadakan seminar bisnis di berbagai kota di seluruh Indonesia, agar ilmu dan pengalamannya bisa bermanfaat bagi semua.

Ketegasan dalam bertindak sangat penting agar peraturan dapat berjalan dengan baik dan tidak melakukan tindakan semena-mena. Akan tetapi, tutur kata dalam menindak lanjuti pelanggaran yang dilakukan juga perlu diperhatikan, agar yang melanggar bisa menyadari kesalahannya dan tidak akan mengulanginya kembali. Dengan ketegasan, apa yang dicita-citakan perusahaan melalui visi misi bisa cepat terealisasikan. Hubungan yang baik akan memberikan dampak yang sangat besar baik itu

\footnotetext{
${ }^{19}$ Andi Prastowo, Metode Penelitian Kualitatif, (Jogjakarta: AR-RUZZ MEDIA, 2012), hal 22

${ }^{20}$ Moh. Nazir, Metode Penelitian, (Bogor: Ghalia Indonesia, 2014), hal 44

${ }^{21}$ Lexy J. Moleong, Metode Penelitian Kualitatif, (Bandung: PT REMAJA ROSDAKARYA, 2013), hal 26
} 
untuk dirinya sendiri maupun orang lain, bahkan untuk perusahaan itu sendiri. Dengan suksesnya membuka 1200 cabang baik di seluruh Indonesia dan di 8 negara telah membuktikan hubungan yang baik dan kepercayaan investor pada perusahaan ini, serta kenyamanan SDM dalam bekerja. Perusahaan memakai nilai asas kekeluargaan,. Jadi dengan kondisi ini suasana tempat kerja bisa kondusif dan nyaman, tidak ada rasa tertekan dalam bekerja dengan cara seperti ini akan menimbulkan rasa kesadaran diri dalam bekerja, secara tidak disadari menjadi giat bekerja dan cekatan.

\section{Kontribusi Motivasi Kerja dalam Pengembangan Usaha}

Kontribusi berdampak sangat luas baik bagi karyawan maupun bagi perusahaan. Bagi karyawan yang mempunyai motivasi tinggi akan memberikan dampak pada penjualan yang tinggi, serta akan mendapatkan imbalan kenaikan gaji atau pangkat. Dan bagi perusahaan dengan track recordnya yang bagus akan memberikan prestasi, yaitu berupa banyaknya penghargaan yang sudah didapat selama 15 tahun menjalankan bisnis. Dalam mengembangkan usaha butuh kesabaran dan keikhasan dalam menjalaninya. Lakukan sesuatu mulai dari yang kecil terlebih dahulu. Ubah masalah menjadi sebuah tantangan, hadapi dengan penuh kesabaran dan keikhlasan, nanti kedepannya akan membuahkan hasil yang lebih baik.

Pendiri KTBR mempunyai tanggung jawab sebagai kepala keluarga adalah hal yang sangat besar, sehingga memotivasi agar bisa memberikan manfaat bagi keluarganya dan masyarakat luas. Hal ini dibuktikan oleh pendiri perusahaan KTBR, yang mana awal mula memiliki tanggung jawab yang besar kepada orang tua dan keluarganya, pendiri bisa memberikan lapangan pekerjaan yang luas bagi orang lain melalui bisnis yang dijalani. Disamping itu juga, pengalaman adalah sebuah pembelajaran berharga agar apa yang akan dilakukan dikemudian hari bisa lebih berhati-hati dalam bertindak. Melalui pengalaman tersebut bisa menjadi acuan dalam mengembangkan usaha kedepan. Semangat terus belajar akan memberikan kontribusi yang sangat besar, hal ini dibuktikan bagaimana pendiri melewati tantangan demi tantangan secara konsisten dan fokus. Hadapi satu demi satu dengan sungguh-sungguh dan kemudian akan menjadi pembelajaran kedepannya nanti.

Ketegasan dalam menyampaikan sesuatu sangat penting. Ketegasan tidak harus berbicara dengan kasar dan bernada tinggi, akan tetapi ketegasan dengan cara yang baik, tutur kata yang halus namun mengena, seperti ketika melakukan kesalahan. Jika disampaikan dengan baik, maka yang bersalah akan menyadari kesalahan dan tidak mengulagi kembali, kontribusinya kinerja perusahaan akan kembali pulih dan baik. Perusahaan ini juga tegas menyampaikan visi dan misinya, yaitu akan menjadi perusahaan makanan kebab terbesar di dunia, menguasai pasar $M E A$ dan lain sebagainya.

Hubungan yang baik akan memberikan kontribusi yang sangat besar. Pertama yang harus di dahului adalah hubungan dengan orang dekat, yaitu keluarga dan saudara-saudara. Semangat emosionalnya akan semakin membara, apalagi restu dari orang tua terutama ibu ini yang membuat usaha semakin berkah. Lingkungan tempat kita bergaul sehari-hari juga akan memberikan kontribusi yang lebih, menambah semangat agar selalu tidak akan pernah menyerah dalam menghadapi tantangan yang ada.

\section{Strategi Pengembangan Waralaba}

Strategi pengembangan waralaba yang diterapkan di PT. Baba Rafi Indonesia melalui 3 kategori, yang pertama melalui media elektronik, seperti menjadi pemateri dalam seminar, masuk siaran di TV, dan lain sebagainya. Kedua, melalui media cetak, seperti majalah wirausaha, meliput di koran, dan lain sebagainya. Ketiga, melalui media online, seperti melalui FB, Twitter, dan lain sebagainya. Selain itu untuk memikat pelanggan supaya bisa kembali membeli lagi, perusahaan ini juga selalu berinovasi memberi menu baru setiap 2 minggu sekali. 
Peneliti menggolongkan ada 4 kriteria strategi pengembangan yang di ambil dari sifat Nabi Muhammad SAW yaitu: pertama, shiddiq : menjaga hubungan baik dengan pelanggan sangatlah penting. Mengingat pelanggan adalah raja, begitu juga dengan investor di perusahaan ini. Memberikan pelayanan yang baik kepada investor sehingga merasa puas dengan hasil kinerja perusahaan, memberikan hasil laba rugi secara benar dan jujur kepada investor. Kedua, amanab: kesungguhan dalam memperbaiki menejemen akan berdampak pada sehat tidaknya perusahaan Ketika perusahaannya sehat, akan meningkatkan rasa kepercayaan investor terhadap perusahaan ini. Ketiga, tabligh: ajakan untuk berfikir secara luas dan global, menjual produk dengan memanfaatkan $M E A$. Strateginya yaitu memperbaiki kemasan, memanfaatkan sumber daya yang ada, memberikan nama branding yang baik. Keempat, fathanah: para pelaku usaha dituntut untuk selalu kreatif dan inovatif dalam berbisnis, mengikuti arus jaman modern, memanfaatkan sosial media buat sarana promosi produk, berani menerima tantangan dikala menghadapi kesulitan dalam berbisnis, tahan banting, dan sebagainya.

\section{Motivasi Kerja Dalam Pengembangan Usaha Perspektif Ekonomi Islam}

Peneliti akan mencoba menghubungkan hasil temuan dengan kerangka teori pada pembahasan sebelumnya yang mana peneliti akan mengaitkan motivasi kerja yang ada di KTBR dengan teori motivasi kerja Herzberg yang oleh peneliti sudah kupas di pembahasan sebelumnya dengan pandangan Ekonomi Islam, sebagai berikut:

\section{Teori Herzberg}

1. Faktor Intrinsik

a. Prestasi : memberikan apresiasi terhadap keberhasilan karyawan adalah hal yang harus dilakukan, dari situ, mereka merasa dihargai atas kinerja yang diberikan. Dalam hal ini bisa pemberian hadiah. Hadiah diperbolehkan dalam islam, akan tetapi jika pemberian hadiah dimaksud sebagai alat untuk memperlancar suatu urusan, ini yang tidak diperbolehkan, karena termasuk unsur suap, dan suap sangatlah dilarang. ${ }^{22}$ Dalam hal ini perusahaan akan memberikan bonus baik berupa kenaikan gaji maupun kenaikan pangkat bagi karyawan yang bisa melampaui target dalam memasarkan produk.

b. Pengakuan : konteks pengakuan dalam hal kekinian khususnya dibidang pekerjaan tidak relevan dan bertentangan dengan ajaran Islam, karena termasuk riya'. Seharusnya ketika bekerja semata-mata karena mengharapkan dan keridhaan Allah SWT (mardhatillah). ${ }^{23}$ Mereka tidak berharap imbalan dari orang lain, bekerja tidak melihat diri. Ikhlas itu bekerja dan bertugas bukan untuk mencari popularitas. ${ }^{24}$ dalam hal ini bisa dilihat pada perusahaan KTBR menerapkan asas kekeluargaan, yang mana disini para karyawan diberi kebebasan dalam mengapresisaikan uneg-unegnya dalam

${ }^{22}$ Dwi Suwiknyo, Kompilasi Tafsir Ayat-Ayat Ekonomi Islam, (Yogyakarta, PUSTAKA PELAJAR, 2010), hal 101

${ }^{23}$ Abdul Halim Usman, Manajemen Strategis Syariah Teori, Konsep dan Aplikasi, (Jakarta, Zikrul Hakim, 2015), hal 71

${ }^{24}$ Ahmad Djalaluddin, Manajemen Qur'ani Menerjemahkan Idarah Ijahiyah dalam Kehidupan, (Malang, UIN Malang Press, 2007), hal 139 
memberikan kontribusi buat perusahaan, dan mereka merasa dihargai sebagai orang yang bisa memberikan kontribusi buat perusahaannya.

c. Tanggung jawab : bertanggung jawab sepenuhnya pada pekerjaan yang dilakukan sebagai kewajiban, jujur dalam melaksanakan kewajiban. Sifat Rasulullah selalu jujur (shiddiq) dalam melaksanakan tugas dan tanggung jawab, sikap jujur berarti selalu melandaskan ucapan, keyakinan serta perbuatan berdasarkan ajaran Islam. ${ }^{25}$ Perusahaan ini sangat menjunjung tinggi nilai kedisiplinan bagi karyawan, hal ini dibuktikan melalui agenda penilaian karyawan secara rutin 6 bulan sekali. Penilaian ini meliputi 6 kategori yaitu, karyawan yang suka menolong, disiplin, ceria, kreatif, relasi yang baik, pendengar yang baik. Hal ini dilakukan supaya buat bahan evaluasi kinerja karyawan supaya bisa bekerja secara efektif dan professional. Sifat tanggung jawab harus ditatap sejak dini, semua harus mempunyai rasa tanggung jawab baik itu buat dirinya maupun buat orang lain, dan juga rasa kejujuran dalam bekerja.

d. Pengembangan : pengembangan sangat penting dalam meningkatkan kemampuan, dalam hal ini manusia diwajibkan untuk terus belajar ( $\left.t a^{\prime} l i m\right)$. Didalam perusahaan ini rutin melakukan breafing setiap hari selasa dan kamis,materinya meliputi pengetahuan tentang keagamaan, nilai-nilai moral dalam bekerja, dan juga mengadakan agenda tausiah rutin setiap 1 bulan sekali, tujuannya untuk keseimbangan antara pekerjaan dan keagamaan.

\section{Faktor Ekstrinsik}

a. Kebijakan dan Administrasi Perusahaan : dalam teori ini yang dimaksud adalah dibidang personalia. Personalia harus cakap dan komunikatif, menyampain dengan benar dan dengan tutur kata yang baik, hal ini tercermin dalam sifat Rasulullah yaitu Tabligh. ${ }^{26}$ Perusahaan ini memakai sikap kekeluargaan, jadi dapat disimpulkan bahwa tidak ada kesenjangan atau kesungkanan antara atasan dan bawahan, selalu membaur bersama, tutur kata atasan tidak menyinggung ketika menasehati bawahan yang melakukan kesalahan.

b. Hubungan antar pribadi : dalam hal ini hubungan (ta'awun) antara atasan dan bawahan seharusnya tidak ada jarak yang menghalangi, karena derajat manusia di mata Allah sama, cuma yang membedakan adalah pada amal dan ibadahnya, dan anjuran Allah untuk saling membantu, pihak yang kuat membantu yang lemah, yang kaya membantu yang miskin agar tidak terjadi ketimpangan sosial dikalangan atasan dan bawahan. hubungan yang terjalin antara para karyawan di perusahaan ini ialah sangat baik, hal tersebut dibuktikan melalui antusias antara para karyawan dalam hal perayaan ulang tahun, mereka rela menyisihkan sebagian kecil penghasilan untuk iuran dan tasyakuran perayaan ulang tahun.

c. Kondisi Kerja : kondisi kerja sangat mempengaruhi tingkat motivasi kerja, oleh karena itu, diharuskan memilih tempat kerja yang mendukung akan kedekatan kita kepada Allah, misalnya, fasilitas tempat ibadah yang memadai dan diwajibkan shalat ketika waktunya telah tiba. Di perusahaan ini peneliti lihat dari kedisiplinan masuk kerja

\footnotetext{
${ }^{25}$ Hermawan Kartajaya, Syariah Marketing, (Bandung, Mizan Pustaka, 2006), hal 123

${ }^{26}$ Kartajaya, Syariah Marketing, hal 132
} 
tepat waktu, suasana yang sangat nyaman, jauh dari kebisingan dan hawanya sejuk dan segar, ini yang membuat semua karyawan yang ada di dalam perusahaan ini sangat nyaman, menjalankan ibadah sangat fleksibel, tidak ada ketentuan harus jam berapa.

d. Gaji : islam menganjurkan agar membayar upah kepada karyawan sebelum keringatnya kering. ${ }^{27}$ Perusahaan ini tidak memberikan informasi mengenai gaji, tapi yang jelas, pembayaran gaji sesuai dengan jobdisknya masing-masing, dan cukup buat biaya hidup.

Setelah mengkaitkan hasil temuan dengan teori pada pembahasan sebelumnya di atas, peneliti akan mencoba mengelompokkan motivasi kerja sesuai dengan fokus penelitian, yaitu sebagai berikut:

\section{Motivasi Kerja Kebab Turki Baba Rafi}

Menelaah hasil dari temuan peneliti pada PT. Baba Rafi Indonesia menyebutkan bahwa motivasi kerja yang diterapkan pada perusahaan ini meliputi aspek kekeluargaan, yang mana dalam hal ini bersifat saling keterbukaan. Disamping itu juga terdapat bonus penjualan, hal ini juga akan mendorong para karyawan bersemangat dalam bekerja.

Perusahaan ini telah menerapat teori motivasi kerja Herzberg, di antaranya:

\section{a. Prestasi}

Karyawan yang mampu bekerja menjual melampaui target akan diberi bonus baik itu berupa tambahan gaji maupun dengan kenaikan jabatan. Memberikan apresiasi penghargaan dalam islam diperbolehkan, akan tetapi jika pemberian hadiah dimaksud sebagai alat untuk memperlancar suatu urusan, ini yag tidak diperbolehkan, karena termasuk unsur suap, dan suap sangatlah dilarang. ${ }^{28}$

b. Tanggung jawab

Perusahaan ini sangat menjunjung tinggi nilai kedisiplinan bagi karyawan, hal ini dibuktikan melalui agenda penilaian karyawan secara rutin 6 bulan sekali. Penilaian ini meliputi 6 kategori yaitu, karyawan yang suka menolong, disiplin, ceria, kreatif, relasi yang baik, pendengar yang baik. Hal ini dilakukan supaya buat bahan evaluasi kinerja karyawan supaya bisa bekerja secara efektif dan professional. Sifat tanggung jawab harus ditatap sejak dini, semua harus mempunyai rasa tanggung jawab baik itu buat dirinya maupun buat orang lain, dan juga rasa kejujuran dalam bekerja, ini tercermin dari sifat Rasulullah. Rasulullah selalu jujur dalam melaksanakan tugas dan tanggung jawab, sikap jujur berarti selalu melandaskan ucapan, keyakinan serta perbuatan berdasarkan ajaran Islam. ${ }^{29}$

c. Pengembangan

${ }^{27}$ https://rumaysho.com/3139-bayarkan-upah-sebelum-keringat-kering.htn di akses tgl 15 oktober 2016 jam $14: 38$

${ }^{28}$ Dwi Suwiknyo, Kompilasi Tafsir Ayat-Ayat Ekonomi Islam, (Yogyakarta, PUSTAKA PELAJAR, 2010), hal 101

${ }^{29}$ Hermawan Kartajaya, Syariah Marketing, (Bandung, Mizan Pustaka, 2006), hal 123 
Perusahaan ini rutin melakukan breafing setiap hari selasa dan kamis, materinya meliputi pengetahuan tentang keagamaan, nilai-nilai moral dalam bekerja, dan juga mengadakan agenda tausiah rutin setiap 1 bulan sekali, tujuannya untuk keseimbangan antara pekerjaan dan keagamaan. Islam mewajibkan ummat manusia agar terus belajar mulai dari lahir hingga sampai ke liang lahat.

\section{d. Kebijakan dan Administrasi Perusahaan}

Perusahaan ini memakai sikap kekeluargaan, jadi dapat disimpulkan bahwa tidak ada kesenjangan atau kesungkanan antara atasan dan bawahan, selalu membaur bersama, tutur kata atasan tidak menyinggung ketika menasehati bawahan yang mempunyai kesalahan, memberikan SP 1,2,3 dengan tutur kata yang baik pula, dan atasan selalu mengecek kondisi lapangan yang ada. Dari sikap itulah, karyawan merasa nyaman dan tak terbebani dalam menjalankan pekerjaan. Dalam hal ini islam mengatakan, tutur kata yang baik dan sopan adalah ciri-ciri pemimpin yang baik. Rasulullah sendiri mempunyai sifat Tabligh.

e. Hubungan antar pribadi

Hubungan yang terjalin antara para karyawan di perusahaan ini yang peneliti temukan ialah sangat baik, hal tersebut dibuktikan melalui antusias antara para karyawan dalam hal perayaan ulang tahun, mereka rela menyisihkan sebagian kecil penghasilan untuk iuran dan tasyakuran perayaan ulang tahun. Islam penjelaskan bahwasannya manusia diciptakan untuk saling melengkapi, semua saling tergantungan, derajat manusia di mata Allah adalah sama, yang membedakan adalah dari amal perbuatannya.

\section{f. Kondisi kerja}

Suasana yang peneliti rasakan selama penelitian di perusahaan ini sangat kondusif. Dilihat dari kedisiplinan masuk kerja tepat waktu, suasana yang sangat nyaman, jauh dari kebisingan dan hawanya sejuk dan segar, ini yang membuat semua karyawan yang ada di dalam perusahaan ini sangat nyaman, menjalankan ibadah sangat fleksibel, tidak ada ketentuan harus jam berapa. Seperti yang sudah kita ketahui bahwasannya suasana di daerah Surabaya sanagtlah panas, ini yang menuntut perusahaan menyediakan suasana tempat yang nyaman, kondusif dan bersih.

\section{Kontribusi Motivasi Kerja dalam Pengembangan Usaha}

Pembahasan kali ini mengenai sumber daya manusia (SDM), yang mana dalam hal ini sangat berperan penting dalam pengembangan dan kemajuan perusahaan, terlihat dari visi dan misi perusahaan ini "berusaha untuk menjadi bisnis waralaba kebab yang terbesar, yang menguntungkan dan yang paling berpengaruh di dunia" dan "Kami berusaha untuk menjadi bisnis waralaba kebab terbesar di dunia dengan menawarkan rasa dan kualitas dengan harga yang terjangkau dan pelayanan yang memuaskan untuk para Franchisee dan pelanggan. Kami juga memiliki tujuan untuk meningkatkan sumber daya manusia dengan mengadakan program dan tanggung jawab sosial yang dapat membantu masyarakat dan pemegang saham". Dari visi dan misi tersebut terdapat gambaran hasrat dan motivasi yang sangat besar, untuk merealisasikan hal tersebut, perusahaan merekrut tenaga professional di bidangnya, di antaranya banyak yang dari lulusan S1 dan S2. Kontribusi yang terlihat disini ialah dari segi kebijakan dan administrasi perusahaan, bagaimana cara atasan menyampaikan sesuatu dan memberikan contoh tindakan yang baik kepada para karyawannya. Hal ini sudah tercerminkan dari sifat Rasulullah yaitu 
tabligh, yang mana antara ucapan dan perbuatan selaran atau sejalan, memberikan teladan yang baik buat ummatnya.

\section{Strategi Pengembangan Waralaba}

Sekilas dari paparan visi dan misi perusahaan tersebut dapat disimpulkan secara tersirat bahwasannya perusahaan ini mempunyai impian yang sangat besar dalam memikat market, dan fokus utama strategi pengembangan dari perusahaan dalam memperkenalkan produk yaitu berusaha menjangkau daerah-daerah luas atau pelosok-pelosok daerah supaya produk kebab banyak dikenal oleh masyarakat di Indonesia. Indonesia merupakan penduduk yang mayoritas beragama Islam, oleh karena itu perusahaan memunculkan produk paket investasi syariah yang mekanismenya sistem bagi hasil, berbagi keuntungan dan berbagi resiko, diharapkan dapat meningkatkan minat para investor dalam berinvestasi di perusahaan ini. Disamping itu juga perusahaan ini menerapkan berbisnis ala Rasulullah,

Ada empat hal yang menjadi key success factors (KSF) dalam mengelola strategi pemasaran syariah, yaitu: ${ }^{30}$

a. Shiddiq (benar dan jujur), jika seorang pengusaha senantiasa berperilaku benar dan jujur dalam sepanjang kegiatannya, jika seorang pemasar bersifat shiddiq haruslah menjiwai seluruh perilakunya dalam melakukan pemasaran, dalam berhubungan dengan pelanggan, dalam bertransaksi dengan nasabah, dan dalam membuat perjanjian dengan mitra bisnisnya. Begitu juga di perusahaan ini menerapkan sistem syariah dalam bisnisnya, seperti bagi hasil, memberikan data yang transparan dan benar dikala bisnisnya menguntungkan, dan berkata sejujurnya dikala bisnis lagi mengalami resiko.

b. Amanah (terpercaya, kredibel), artinya, dapat dipercaya, bertanggung jawab, dan kredibel, juga bermakna keinginan untuk memenuhi sesuatu sesuai dengan ketentuan. Diantara nilai yang terkait dengan kejujuran dan melengkapinya adalah amanah. Perusahaan ini memberikan jaminan return yang menjanjikan kepada para investor, karena dalam bisnis di perusahaan ini sudah berjalan lebih dari 13 tahun dan telah teruji keberhasilannya.

c. Tablig (komunikatif), artinya komunikatif dan argumentatif dengan tutur kata yang tepat dan mudah dipahami. Dalam bisnis, haruslah menjadi seorang yang mampu mengomunikasikan visi dan misinya dengan benar kepada karyawan dan stakeholder lainnya. Juga menyampaikan keunggulan-keunggulan produknya dengan jujur dan tidak harus berbohong maupun menipu pelanggan. Perusahaan ini sudah jelas dalam memberikan pelayanan yang baik, menjelaskan manfaat yang akan diterima jika menjadi investor di perusahaan ini, memberikan bukti, track record, dan penghargaan yang sudah diterima oleh perusahaan selama ini, sehingga akan memberikan kepercayaan yang lebih buat para investor dalam mengembangkan usaha ini.

d. Fathanah (cerdas), dapat diartikan sebagai intelektual, kecerdikan atau kebijaksanaan. Pemimpin yang fathanah adalah pemimpin yang memahami, mengerti, dan menghayati secara mendalam segala hal yang menjadi tugas dan kewajibannya. Dalam bisnis, implikasi ekonomi sifat fathanah adalah bahwa segala aktivitas dalam manajemen suatu perusahaan harus dengan kecerdasan, dengan mengoptimalkan semua potensi akal yang ada untuk mencapai tujuan. ${ }^{31}$ Hal ini sudah diterapkan oleh perusahaan bahwasanya perusahaan merekrut banyak tenaga ahli dibidangnya, salah satunya banyak lulusan dari S1 dan S2, agar supaya managemen perusahaan menjadi sehat.

${ }^{30}$ Tresnati Ratih, Nina Maharani, 2015, Jurnal Menejemen: Kajian Tentang Strategi Pemasaran Syariah Dalam Penguatan Daya Saing UMK Menghadapi AEC 2015 Di Indonesia, Bandung, UNISBA, 2015). Hal 5

${ }^{31}$ Hermawan Kertajaya dan Muhammad Syakir Sula, Syariah Marketing, (Bandung, Mizan Pustaka, 2006) hal $120-135$ 


\section{PENUTUP}

Motivasi kerja dalam pengembangan usaha pada perusahaan PT. Baba Rafi Indonesia menerapkan 6 faktor, pertama prestasi yaitu memberikan apresiasi terhadap karyawan yang dapat melampaui target penjualan dengan cara baik itu dapat hadiah, kenaikan gaji atau pangkat, kedua tanggung jawab yaitu menjunjung tinggi nilai kedisiplinan dan menjalankan aturan yang berlaku, ketiga pengembangan yaitu memberikan breafing berupa tausiah pendalaman agama setiap sebulan sekali, keempat kebijakan administrasi yaitu memakai asas kekeluargaan, yang mana diharapkan dapat memberikan keleluasaan dalam memberikan masukan-masukan demi meningkatkan perkembangan di perusahaan, kelima bubungan antar pribadi yaitu saling perhatian antar sesama karyawan dengan cara merayakan ulang tahun bersama, keenam kondisi kerja yaitu menyediakan fasilitas kerja yang lengkap guna memberikan kenyamanan dalam menjalankan tugas

Kontribusi motivasi kerja dalam pengembangan waralaba di PT. Baba Rafi Indonesia terletak pada kebijakan dan administrasi perusahaan, yang mana pemimpin sebagai roda pengendali kebijakan perusahaan telah memberikan contoh yang baik, sosok pemimpin yang santun dan welcome. Disisi lain juga membuka mata rantai rezeki dengan menciptakan lapangan pekerjaan baru. Fokus utama strategi pengembangan dari perusahaan dalam memperkenalkan produk yaitu berusaha menjangkau daerah-daerah luas atau pelosok-pelosok daerah supaya produk kebab banyak dikenal oleh masyarakat di Indonesia. Disamping itu juga strategi pengembangan pada perusahaan ini telah menerapkan prinsip bisnis ala Rasulullah yang di antaranya adalah, shiddiq, amanah, tabligh, dan fatanah.

\section{DAFTAR PUSTAKA}

Anoraga, Pandji, 1992, Psikologi Kerja. Jakarta : PT Rineka Cipta.

Anwar ,Prabu Mangkunegara, 1993, Psikologi perusahaan, Bandung: Trigenda karya.

Buchari, Zainun, 1989, Manajemen dan Motivasi, Jakarta, Balai Aksara.

Djalaluddin, Ahmad, 2007, Manajemen Qur'ani Menerjemabkan Idarah Ijabiyah dalam Kebidupan, Malang, UIN Malang Press.

Ekotama, Suryono, 2008, Cara Gampang Bikin Bisnis Franchise, Yogyakarta: Media Pressindo.

Gatut Susanto dan M.Azrin Syamsuddin, 2009, Cara Mudah Mendirikan dan Mengelola UMKM, Cetakan pertama, Depok, Raih Asa Sukses.

Hasibuan, Melayu, 2001, Managemen dasar, pengertian dan masalah. Refisi F. d. Jakarta : Rajawali.

Husein Umar, 2002. Metode Riset Bisnis, Jakarta, PT. Gramedia Pustaka Utama.

Kartajaya, Hermawan, 2006, Syariah Marketing, Bandung, Mizan Pustaka

Moleong, Lexy J, 2013, Metode Penelitian Kualitatif, Bandung: PT REMAJA ROSDAKARYA.

Nazir, Moh, 2014, Metode Penelitian, Bogor: Ghalia Indonesia.

Prastowo, Andi, 2012, Metode Penelitian Kualitatif, Jogjakarta: AR-RUZZ MEDIA.

Rachmadi, Bambang N, 2007, Franchising The most Practical and Excellent Way of Succeeding, Cetakan kedua, Jakarta, Gramedia Pustaka Utama.

Sanusi, Azwar, 2012, Tesis Pengaruh Kerja dan Iklim Komunikasi Organisasi terbadap Komitmen Keorganisasian Pegawai Arsip Nasional Republik Indonesia,, Universitas Indonesia.

Stephen P. Robbins, Timothy A. Judge, 2008, Perilaku Organisasi, edisi ke 12 buku 1, Jakarta: Salemba empat.

Sulistyono, Adi, 2009, Hukum Ekonomi Sebagai Panglima, Cetakan pertama, Sidoarjo, Masmedia Buana Pustaka.

Suwiknyo, Dwi, 2010, Kompilasi Tafsir Ayat-Ayat Ekonomi Islam, Yogyakarta, PUSTAKA PELAJAR. 
Tresnati Ratih, Nina Maharani, 2015, Jurnal Menejemen: Kajian Tentang Strategi Pemasaran Syariah Dalam Penguatan Daya Saing UMK Menghadapi AEC 2015 Di Indonesia, Bandung, UNISBA.

Usman, Abdul Halim, 2015, Manajemen Strategis Syariab Teori, Konsep dan Aplikasi, Jakarta, Zikrul Hakim.

Veithzal, Rivai, 2004, Managemen Sumber Daya Manusia Untuk Perusahaan, Dari Teori Ke Preaktek, Jakarta, PT. Raja Grafindo Persada.

http://sp.beritasatu.com/ekonomidanbisnis/kebab-baba-rafi-rambah-malaysia-dan-filipina/17072

https://rumaysho.com/3139-bayarkan-upah-sebelum-keringat-kering.htn 